\title{
PEMANFAATAN PELAYANAN SOSIAL LEMBAGA KONSULTASI KESEJAHTERAAN KELUARGA OLEH ANAK KORBAN TINDAK KEKERASAN DI KOTA CIMAHI PROVINSI JAWA BARAT
}

\author{
Arfianti Daniasari \\ Politeknik Kesejahteraan Sosial Bandung, Jl. Ir. H. Juanda No. 367, Dago, Bandung \\ 40135, Arfiantid04@gmail.com \\ Meilani Dewi Setiamanah \\ Politeknik Kesejahteraan Sosial Bandung, Jl. Ir. H. Juanda No. 367, Dago, Bandung \\ 40135, mdsetiah@yahoo.co.id
}

\begin{abstract}
This study describes the Utilization of Family Welfare Consultation Institution Services (LK3) by Children Victims of Violence in Cimahi City, West Java Province. This study aims to obtain an overview of: 1) Characteristics of Informants; 2) Utilization of Information Services; 3) Outreach; 4) Consultation, 5) Counseling; 6) Advocacy; and 7) LK3 referral by child victims of violence in Cimahi City. The theory used in this study uses the theory of social child welfare social services. This research uses descriptive method with a qualitative approach. Informants in this study were 11 informants consisting of child victims of violence, families, administrators of Cimahi City LK3, and the police. The determination of this informant uses a purposive technique. Data collection techniques using in-depth interviews, observation and documentation study.The results showed that child victims of violence used LK3 social services in the form of information services, outreach, consultation, counseling, advocacy, referral with the assistance of parents who assisted during the utilization process. Utilization is known from the efforts in the form of intensity, type, source, media and process during service use and the results obtained. Information services have been utilized but have not been maximized due to lack of knowledge and information regarding the form and function of LK3 services, so an improvement is needed. Based on this, it is necessary to have activities to increase the knowledge and understanding of Children Victims of Violence in order to take advantage of LK3 social services. In addition, it is also necessary to strengthen the capacity of LK3 officers so that they can provide adequate services and assistance to children who experience violence and their families
\end{abstract}

\section{Keywords:}

Utilization of Social Services; Family Welfare Consultation Institutions; Children Victims of Violence

\footnotetext{
Abstrak

Penelitian ini menggambarkan tentang Pemanfaatan Pelayanan Sosial Lembaga Konsultasi Kesejahteraan Keluarga (LK3) oleh Anak Korban Tindak Kekerasan di Kota Cimahi Provinsi Jawa Barat. Penelitian ini bertujuan untuk memperoleh gambaran tentang: 1) Karakteristik Informan; 2) Pemanfaatan Pelayanan Informasi; 3)
} 
Penjangkauan; 4) Konsultasi, 5) Konseling; 6) Advokasi; dan 7) Rujukan LK3 oleh anak korban tindak kekerasan di Kota Cimahi. Teori yang digunakan dalam penelitian ini menggunakan teori kesejahteraan anak serta pelayanan sosial anak. Penelitian ini menggunakan metode deskriptif dengan pendekatan kualitatif. Informan dalam penelitian ini sebanyak 11 informan terdiri dari anak korban kekerasan, keluarga, pengurus LK3 Kota Cimahi, dan kepolisian. Penentuan informan ini menggunakan teknik purposive. Teknik pengumpulan data menggunakan wawancara mendalam, observasi dan studi dokumentasi. Hasil penelitian menunjukkan bahwa anak korban tindak kekerasan telah memanfaatkan pelayanan sosial LK3 berupa pelayanan informasi, penjangkauan, konsultasi, konseling, advokasi, rujukan dengan bantuan orang tua yang mendampingi selama proses pemanfaatan berlangsung. Pemanfaatan tersebut diketahui dari upaya berupa intensitas, jenis, sumber, media dan proses selama pelayanan digunakan serta hasil yang diperoleh. Pelayanan informasi telah dimanfaatkan namun belum maksimal karena kurangnya pengetahuan dan informasi mengenai bentuk dan fungsi pelayanan LK3 sehingga dibutuhkan peningkatan. Berdasarkan hal tersebut perlu adanya kegiatan untuk meningkatkan pengetahuan dan pemahaman Anak Korban Tindak Kekerasan untuk memanfaatkan pelayanan sosial LK3. Selain itu juga perlu diberikan penguatan kapasitas petugas LK3 sehingga dapat memberikan pelayanan dan pendampingan yang memadai terhadap anak yang mengalami tindak kekerasan dan keluarganya.

\section{Kata Kunci:}

Pemanfaatan Pelayanan Sosial; LK3; Anak Korban Tindak Kekerasan 


\section{PENDAHULUAN}

Menurut Komisi Perlindungan Anak Indonesia (KPAI:2017) kasus kekerasan terhadap anak di Indonesia relatif mengalami penurunan, seperti kekerasan anak pada tahun 2016 sejumlah 3.339 kasus, tahun 2017 sejumlah 2.737 kasus. Selain itu, jumlah tersebut masih belum mencakup korban yang tidak melapor. Namun, hal tersebut tidak mengindikasikan bahwa kekerasan pada anak secara nasional menurun kasusnya. Justru, kasus kekerasan seksual pada anak masih terus mendominasi. Kekerasan terhadap anak merupakan tindakan melukai dan tidak bertanggung jawab sehingga menimbulkan dampak negatif bagi anak baik secara fisik, psikis maupun sosial.

Berdasarkan data yang ada hampir 80 persen kasus kekerasan terhadap anak di Indonesia cenderung dilakukan oleh orang terdekat. Pelaku kandung sebanyak 91 dan tiri 66 pelaku, lainnya merupakan teman, tetangga, teman, pengasuh, dan guru (www.viva.co.id). Kedekatan hubungan yang dimiliki oleh anak dengan pelaku seringkali digunakan untuk menutupi tindakannya, sehingga tidak dicurigai oleh masyarakat ataupun keluarga yang lain. Pelaku yang mengetahui situasi dan aktivitas dari korban membuat pelaku lebih leluasa dalam melakukan tindakan kekerasannya terhadap anak. Hal ini diperkuat data Komisi Perlindungan Anak Indonesia (2017) terdapat tahun 2011 sampai 2016 sebanyak 4.294 kasus kekerasan pada anak dilakukan oleh keluarga dan pengasuh.

Jumlah kasus kekerasan terhadap anak di Jawa Barat menurut data Pusat Pelayanan Terpadu Pemberdayaan Perempuan dan Anak (P2TP2A) selama kurun waktu enam tahun terdapat 1.224 kasus terjadi dari 27 kota/kabupaten di Jawa Barat. Berdasarkan data P2TP2A Jawa Barat bahwa jumlah kasus kekerasan terhadap anak di Jawa Barat sepanjang tahun 2016 terdapat 346 kasus dan tahun 2017 tercatat ada 160 kasus kekerasan pada anak.

Kota Cimahi merupakan salah satu daerah di Jawa Barat yang memiliki jumlah kasus kekerasan cukup tinggi. Data kasus kekerasan terhadap anak yang telah ditangani oleh Lembaga Konsultasi Kesejahteraan Keluarga Kota Cimahi pada tahun 2017 sebanyak 14 kasus dan tahun 2018 sejumlah 15 kasus kekerasan pada anak dengan rentang usia antara 5-15 tahun. Korban terdiri dari jenis kelamin perempuan maupun laki-laki. Kekerasan yang terjadi dalam rentang waktu 2017 sampai 2018 yang terjadi meliputi kekerasan fisik, kekerasan seksual dan kekerasan psikis.

Mayoritas jumlah kasus kekerasan yang terjadi yaitu kekerasan seksual berupa pemerkosaan. Jenis kasus kekerasan di Kota Cimahi tahun 2018 berdasarkan data LK3 Kota Cimahi yaitu terdapat kekerasan psikis sebanyak 1 anak dan kekerasan seksual sebanyak 14 anak. Pelaku kekerasan terhadap anak yang terjadi di Kota Cimahi sesuai dengan data LK3 Kota Cimahi berasal dari lingkungan keluarga seperti saudara kandung, tetangga terdekat, guru, maupun orang asing. Pengaduan kasus kekerasan anak yang ditangani pihak LK3 diperoleh dari laporan di Kepolisian, P2TP2A, Dinas Sosial Pengendalian Penduduk dan Keluarga Berencana Pemberdayaan Perempuan dan Perlindungan (P2KBP3A) Kota Cimahi, kejaksaan, pengadilan dan LK3 maupun laporan langsung dari masyarakat atau korban.

Kesadaran masyarakat untuk melapor masih dirasakan kurang. Fenomena ini merupakan suatu peristiwa gunung es. Kasus 
kekerasan terhadap anak sulit untuk diungkap disebabkan oleh beberapa hal menurut Suharto dalam Abu Huraerah (2018) yaitu karena penolakan dari korban, keluarga yang cenderung menutupi karena dianggap aib keluarga yang memalukan, maupun masyarakat yang kurang mengetahui tanda pada diri anak yang mengalami kekerasan. Kondisi tersebut menuntut adanya pemecahan masalah sehingga angka kekerasan di Indonesia dapat terus mengalami penurunan.

Penanganan kasus kekerasan terhadap anak telah dilakukan beberapa pihak termasuk pemerintah dengan membuka aduan terkait tindak kekerasan melalui Komisi Perlindungan Anak Indonesia (KPAI)/Kementerian Sosial, mengeluarkan Undang-Undang Nomor 35 tahun 2014 tentang Perlindungan Anak, pemberian sanksi/hukuman berat berupa kurungan penjara maupun denda nyatanya belum mampu mengatasi jumlah kasus kekerasan yang masih cukup tinggi.

Kasus kekerasan terhadap anak seharusnya menjadi perhatian yang serius oleh berbagai pihak, untuk itu perlunya peran serta seluruh pihak baik pemerintah, keluarga, masyarakat maupun lembaga/organisasi sehingga jumlah kasus tersebut dapat diminimalisir. Pelayanan sosial dan penanganan masalah anak korban sangat dibutuhkan dalam upaya pencegahan (preventive) dan memperbaiki (rehabilitatif). Pelayanan sosial sendiri merupakan suatu usaha-usaha yang terorganisir sehingga dapat membantu individu, keluarga, maupun masyarakat sehingga dapat berfungsi sosial. Pelayanan sosial dalam penanganan anak korban kekerasan di Kota Cimahi diberikan oleh berbagai pihak dari tahap pelaporan hingga penanganan langsung. Penanganan kekerasan terhadap anak di Kota Cimahi juga dilakukan oleh Lembaga Konsultasi Kesejahteraan Sosial Keluarga (LK3).

LK3 merupakan organisasi yang memberikan pelayanan konsultasi, konseling, pemberian/penyebarluasan informasi, penjangkauan, advokasi, dan pemberdayaan bagi keluarga secara profesional, termasuk merujuk sasaran ke lembaga pelayanan lain yang mampu memecahkan masalahnya secara lebih intensif. LK3 ini didirikan oleh pemerintah, pemerintah daerah atau masyarakat, dimana keberadaan LK3 diharapkan dapat menjadi centre link terhadap semua layanan keluarga. LK3 memiliki sasaran pelayanan yaitu keluarga yang membutuhkan informasi dan advokasi dalam pengembangan kualitas keluarga.

LK3 ini ditujukan kepada keluarga yang membutuhkan bantuan penanganan masalah psikologis, sosial (psikososial), maupun individu, kelompok, institusi yang karena keperduliannya mengatasi masalah keluarga. Permasalahan yang ditangani oleh LK3 meliputi kasus dalam lingkup keluarga seperti kasus Kekerasan dalam Rumah Tangga (KDRT), masalah psikososial lanjut usia, disabilitas, anak, dan termasuk kekerasan anak.

LK3 Kota Cimahi merupakan salah satu lembaga yang memberikan pelayanan sosial dan penanganan kasus terhadap anak korban tindak kekerasan yang bekerjasama dengan pihak kepolisian, Balai Pemasyarakatan (BAPAS), dan P2TP2A, Lembaga Perlindungan Anak (LPA), dan Dinas Kesehatan. LK3 Kota Cimahi ialah lembaga milik pemerintah Kota Cimahi dibawah Dinas Sosial Pengendalian Penduduk dan Keluarga Berencana Pemberdayaan Perempuan dan Perlindungan Anak (P2KBP3A) Kota Cimahi. Lembaga ini berperan dalam memberikan pelayanan sosial dengan tujuan agar individu 
dan keluarga dapat memecahkan permasalahan sosial yang dialami dan mencapai kesejahteraan. Jumlah kasus yang telah ditangani LK3 Kota Cimahi pada tahun 2016 sebanyak 170 kasus, tahun 2017 sebanyak 67 kasus, dan tahun 2018 sebanyak 56 kasus. Kasus tersebut mencakup masalah yang membutuhkan penanganan psikososial dalam keluarga seperti KDRT, lansia, disabilitas, permasalahan anak perdagangan dan penelantaran anak termasuk masalah kekerasan anak.

Pelaksanaan pelayanan sosial yang diberikan oleh LK3 Kota Cimahi dalam penanganan anak korban tindak kekerasan menurut Peraturan Menteri Sosial Republik Indonesia No 25 Tahun 2017 tentang Lembaga Konsultasi Kesejahteraan Keluarga meliputi pelayanan informasi, penjangkauan, konseling, konsultasi, advokasi, dan rujukan. Pelayanan informasi yang dilakukan oleh LK3 dengan melakukan penyuluhan kepada masyarakat terkait pencegahan kekerasan terhadap anak bekerjasama dengan mahasiswa, mensosialisasikan terkait syarat dan prosedur pelayanan.

Proses penjangkauan dilakukan dengan melakukan home visit ke rumah korban setelah mendapatkan pelaporan. Penjangkauan ini dilakukan untuk membangun relasi sekaligus melakukan konseling dan konsultasi. Informasi alamat serta nomor telepon keluarga yang kurang jelas sering kali menjadi penghambat dalam proses penjangkauan. Pelayanan konsultasi dan konseling dilakukan di rumah korban atau di ruang konseling LK3 Kota Cimahi. Konseling dan konsultasi yang dilakukan di rumah selama 2-3 kali hal tersebut dikarenakan kondisi korban yang masih trauma dan tidak mau keluar dari kamar. Konsultasi dan konseling yang diberikan oleh pihak LK3
Kota Cimahi tidak hanya kepada korban tetapi juga kepada keluarga atau kerabat korban. Konseling yang diberikan kepada orang tua atau kerabat berupa pola asuh dan cara menghadapi dengan baik terkait anak yang mengalami kekerasan. Pelaksanaan konseling yang dilakukan oleh pihak LK3 Kota Cimahi sering kali didampingi oleh tenaga profesional lain seperti konselor/psikolog dari Crisis Centre Universitas Jendral Ahmad Yani (UNJANI).

Advokasi dan rujukan dilakukan ketika korban membutuhkan pelayanan lebih seperti pemeriksaan kesehatan (visum) yang tidak dapat disediakan oleh pihak LK3 termasuk mengadvokasikan ke lembaga atau sumber yang dibutuhkan. Advokasi seperti yang dilakukan pihak LK3 Kota Cimahi terhadap pihak kepolisian saat proses penyidikan ketika belum dilanjutkan setelah adanya pelaporan di kepolisian.

Pelayanan yang diberikan dilakukan oleh ketua, sekretaris, dan bendahara yang merupakan pekerja sosial dibantu oleh tenaga profesional lainnya seperti dokter, jaksa, dan psikolog. Selain itu, pelayanan yang diberikan dengan persetujuan pihak keluarga. Jangka waktu pelayanan terhadap anak korban tindak kekerasan kurang lebih satu tahun. Proses tersebut meliputi tiga bulan meliputi kegiatan penjangkauan dan pemulihan kejiwaan (konseling dan konsultasi) dan tiga bulan pemulihan trauma selama proses persidangan. Pemberian pelayanan disesuaikan dengan fungsi lembaga ini yaitu pencegahan, pengembangan, rehabilitasi dan penunjang.

Pemanfaatan sendiri merupakan hal, cara, proses dalam menggunakan dan mengambil daya guna dari sesuatu yang bermanfaat. Pemanfaatan pelayanan LK3 Kota Cimahi oleh anak korban tindak kekerasan di Kota Cimahi 
dapat diukur dengan melihat bahwa korban mengetahui dan mampu mengikuti pelayanan yang diberikan dengan baik dan menyeluruh, mendapatkan tujuan dari pelayanan, waktu pelayanan, mampu mengatasi permasalahan yang dimilikinya dan kasusnya dapat terselesaikan. Berdasarkan isu dan fakta tersebut peneliti tertarik untuk melakukan penelitian mengenai pemanfaatan pelayanan sosial LK3 oleh anak korban tindak kekerasan di Kota Cimahi. Pemanfaatan Pelayanan Sosial Lembaga Konsultasi Kesejahteran Keluarga (LK3) oleh Anak Korban Tindak Kekerasan di Kota Cimahi Provinsi Jawa Barat dikaji berdasarkan aspek-aspek yaitu:

Karakteristik Informan; (2) Pemanfaatan Pelayanan Informasi; (3) Pelayanan Penjangkauan, (4) Pelayanan Konsultasi; (5) Pelayanan Konseling; (6) Pelayanan Advokasi, dan (7) Pelayanan Rujukan.

\section{METODE}

Penelitian ini menggunakan pendekatan kualitatif dengan metode deskriptif. Penelitian ini bertujuan untuk memperoleh gambaran mengenai bagaimana pemanfaatan pelayanan sosial LK3 oleh anak korban tindak kekerasan di Kota Cimahi. Jumlah Informan penelitian ini sebanyak 11 orang yang ditentukan dengan teknik purposive. Teknik pengumpulan data berupa wawancara mendalam, observasi, dan studi dokumentasi. Pemeriksaan keabsahan data menggunakan teknik ketekunan pengamatan, perpanjangan pengamatan, triangulasi, dan kecukupan referensi. Teknik analisis data dilakukan dengan cara reduksi data, penyajian data, dan penarikan kesimpulan.

\section{HASIL PENELITIAN}

Hasil penelitian menunjukkan bahwa pemanfaatan pelayanan sosial LK3 oleh anak korban tindak kekerasan di Kota Cimahi dilakukan dengan berbagai upaya berupa intensitas, jenis, sumber, tujuan, media, dan proses selama pelayanan digunakan serta hasil yang diperoleh setelah memanfaatkan pelayanan sosial LK3. Pemanfaatan pelayanan sosial LK3 Kota Cimahi sebagai upaya memperoleh pemecahan permasalahan psikososial yang dialami anak anak korban tindak kekerasan di Kota Cimahi

\section{Karakteristik Informan}

Karakteristik informan terdiri dari anak korban tindak kekerasan, keluarga/kerabat dari anak korban tindak kekerasan, pengurus LK3 dan mitra kerja LK3 yaitu kepolisian. Berikut ini merupakan karakteristik informan dalam penelitian ini :

\section{Matriks 1.1. Karakteristik Informan} Penelitian

\begin{tabular}{|c|c|c|c|c|c|}
\hline $\begin{array}{l}\mathrm{N} \\
\mathrm{O}\end{array}$ & Inisial & $\begin{array}{l}\text { Us } \\
\text { ia }\end{array}$ & JK & $\begin{array}{c}\text { Pendidi } \\
\text { kan }\end{array}$ & Status \\
\hline 1. & $\mathrm{AL}$ & 15 & $\mathrm{P}$ & $\begin{array}{l}\text { SD } \\
\text { (putus } \\
\text { sekolah) }\end{array}$ & $\begin{array}{l}\text { Anak } \\
\text { Korban } \\
\text { Kekerasan } \\
\text { Seksual }\end{array}$ \\
\hline 2. & $\mathrm{DH}$ & 44 & $\mathrm{P}$ & SMP & $\begin{array}{l}\text { Ibu } \\
\text { Kandung } \\
\text { AL }\end{array}$ \\
\hline 3. & SMT & 11 & $\mathrm{P}$ & $\mathrm{SD}$ & $\begin{array}{l}\text { Anak } \\
\text { Korban } \\
\text { Kekerasan } \\
\text { Seksual }\end{array}$ \\
\hline 4. & AW & 42 & $\mathrm{~L}$ & SMK & $\begin{array}{l}\text { Ayah Tiri } \\
\text { SMT }\end{array}$ \\
\hline 5. & SMY & 10 & $\mathrm{P}$ & SD & $\begin{array}{l}\text { Anak } \\
\text { Korban } \\
\text { Kekerasan } \\
\text { Seksual } \\
\end{array}$ \\
\hline 6. & $\mathrm{JJ}$ & 28 & $\mathrm{P}$ & SD & $\begin{array}{l}\text { Ibu } \\
\text { Kandung } \\
\text { SMY }\end{array}$ \\
\hline
\end{tabular}




\begin{tabular}{|l|l|l|l|l|l|}
\hline 7. & ME & 28 & P & SMK & $\begin{array}{l}\text { Pengasuh } \\
\text { Panti } \\
\text { SMY }\end{array}$ \\
\hline 8. & RD & 52 & P & $\begin{array}{l}\text { S1 } \\
\text { Kesejah } \\
- \text { teraan } \\
\text { Sosial }\end{array}$ & $\begin{array}{l}\text { Pengurus } \\
\text { LK3 Kota } \\
\text { CImahi }\end{array}$ \\
\hline 9. & GT & 28 & $\mathrm{P}$ & $\begin{array}{l}\text { S1 Ilmu } \\
\text { Komuni } \\
\text {-kasi }\end{array}$ & $\begin{array}{l}\text { Pengurus } \\
\text { LK3 Kota } \\
\text { Cimahi }\end{array}$ \\
\hline 10 & NT & 34 & P & $\begin{array}{l}\text { Sekolah } \\
\text { Kepolisi } \\
- \text { an }\end{array}$ & $\begin{array}{l}\text { Kepolisi } \\
\text {-an Polres } \\
\text { Cimahi }\end{array}$ \\
\hline 11 & SF & 45 & L & $\begin{array}{l}\text { Sekolah } \\
\text { Kepolisi } \\
\text { a-n }\end{array}$ & $\begin{array}{l}\text { Kepolisi } \\
\text {-an Polres } \\
\text { Cimahi }\end{array}$ \\
\hline
\end{tabular}

Matriks 1.1 menunjukkan bahwa karakteristik informan yang beragam. Keberagaman karakteristik mempengaruhi informasi dan proses pemanfaatan pelayanan sosial LK3 yang dilakukan oleh anak korban kekerasan di Kota Cimahi. Hal ini berarti bahwa proses pelayanan yang diberikan LK3 berbeda-beda disesuaikan dengan kondisi karakteristik dari korban. Anak sebagai korban akan mendapatkan perbedaan pelayanan dibandingkan dengan keluarga/kerabat dari korban karena kondisi trauma yang dialaminya.

Berdasarkan hasil penelitian diperoleh karakteristik dari 11 informan. Informan utama maupun pendukung berusia antara 10-52 tahun. Usia informan utama yang terdiri dari tiga anak korban tindak kekerasan berada dalam rentang usia 10-15 tahun dengan jenis kekerasan seksual. Usia anak korban tindak kekerasan dari ketiga informan tersebut sesuai dengan kriteria yang ada di Peraturan Menteri Sosial Republik Indonesia Nomor 8 Tahun 2012 berada dibawah usia 18 tahun.

Tingkat pendidikan orang tua mempengaruhi bagaimana seorang anak korban tindak kekerasan memanfaatkan pelayanan sosial LK3. Dukungan orang tua mempengaruhi bagaimana anak korban tindak kekerasan dapat memanfaatkan pelayanan sosial LK3. Berdasarkan informasi dari ketiga orang tua anak korban tindak kekerasan diketahui bahwa AW yang memiliki tingkat pendidikan yang lebih tinggi dibandingkan dengan $\mathrm{JJ}$, dan $\mathrm{DH}$ memanfaatkan pelayanan sosial dari LK3 lebih baik.

Kekerasan yang dialami oleh anak berdampak pada kondisi psikis maupun sosial dimana anak menjadi lebih agresif atau sebaliknya menjadi pendiam dan menarik dari lingkungan sesuai teori yang disampaikan oleh Pinky dalam Bagong Suyanto (2003). Hal tersebut ditemukan pada informan anak korban tindak kekerasan yang menunjukkan sikap menarik diri dari lingkungan pergaulan. Sikap tertutup yang ditunjukkan ketiga informan juga mempengaruhi cara menjawab pertanyaan dari peneliti yang tidak dapat secara rinci dan cenderung dalam keadaan lupa. Kondisi ini pula menyebabkan proses pemanfaatan pelayanan sosial seringkali membutuhkan waktu yang cukup lama, dikarenakan anak belum mau terbuka dalam melaksanakan proses pelayanan sosial LK3. Anak yang sulit untuk menyampaikan apa yang dirasakannya menyebabkan ketidaktahuan orang tua mengenai kondisi anaknya, sehingga pemanfaatan pelayanan tidak secara maksimal dilakukan karena orang tua menganggap anaknya sudah baik-baik saja. Anak yang menjadi korban kekerasan pada penelitian ini diketahui semuanya berjenis kelamin perempuan. Hal ini sesuai dengan teori yang disampaikan oleh Harkrisnowo dalam Bagong (2010) yang menyatakan 
bahwa jumlah kekerasan lebih banyak terjadi pada perempuan karena secara structural anak perempuan lebih vulnerable, lebih lemah, tergantung, dan mudah dikuasai, dan diancam oleh pelaku. Selain itu, kasus kekerasan yang dialami oleh informan anak yang menjadi korban tindak kekerasan disebabkan oleh faktor lingkungan sosial sesuai pendapat Ismail dalam Bagong (2003) yaitu kondisi ekonomi keluarga yang rendah. Kondisi ekonomi yang rendah dari keluarga informan tersebut mempengaruhi kurangnya pemenuhan kebutuhan anak dan seperti dalam memberikan rasa aman, perlindungan, dan kasih sayang.

Kebutuhan anak yang seharusnya dipenuhi orang tua seperti yang diungkapkan oleh Muhidin dalam Abu Huraerah (2018) meliputi perlindungan (keamanan), kasih sayang dan perhatian, akan tetapi pada kenyataannya tidak terpenuhi dengan baik kepada anak menyebabkan kasus kekerasan dapat terjadi. Orang tua yang sibuk bekerja serta pola asuh kurang tepat menyebabkan anak kurang mendapatkan pengawasan serta perhatian sehingga anak tidak bisa secara terbuka bercerita kepada orang tuanya mengenai kejadian yang dialaminya. Hal tersebut juga sesuai dengan pendapat Suharto dalam Abu Huraerah (2018) yang menyebutkan bahwa seringkali masyarakat tidak mengetahui secara jelas tanda-tanda pada diri anak yang mengalami kekerasan.

\section{Pemanfaatan Pelayanan Informasi}

Pelayanan informasi LK3 menurut Direktorat Pemberdayaan Keluarga dan Kelembagaan Sosial Kesejahteraan Keluarga (2011) berupa pemberian informasi mengenai program pelayanan dan ketersediaan sumber pelayanan dalam penanganan kasus. Berdasarkan hasil penelitian dapat diketahui bahwa anak korban tindak kekerasan telah memanfaatkan pelayanan informasi untuk mengetahui informasi terkait penanganan kondisi anak yang mengalami trauma.

Pemanfaatan pelayanan terkait jenis informasi untuk mendapatkan informasi terkait program pelayanan LK3 cenderung kurang, dimana mereka kurang memiliki upaya untuk mengetahui bentuk pelayanan apa saja yang ada dan diberikan oleh LK3. Selain itu, LK3 seharusnya mampu memberikan informasi mengenai program pelayanan dan ketersediaan sumber pelayanan yang dimilikinya, pada kenyataanya anak dan keluarga tidak memperoleh secara jelas informasi mengenai kelembagaan dan bentuk pelayanannya. Hal tersebut dimungkinkan pemanfaatan pelayanan lebih maksimal ketika anak maupun keluarga mengetahui manfaat dari pelayanan yang diperoleh.

\section{a. Sumber Informasi}

Pemanfaatan pelayanan sosial berdasarkan hasil penelitian diketahui bahwa sumber anak korban tindak kekerasan dalam menggunakan pelayanan informasi berasal dari informasi keluarga dan mitra kerja baik kepolisian, maupun pekerja sosial masyarakat. Informasi mengenai pelayanan LK3 dari pihak keluarga dikarenakan kasus kekerasan yang dialami anak seringkali tidak diketahui oleh banyak pihak dan keluarga merupakan pihak terdekat dari korban yang mengetahui kejadian yang dialami sehingga informasi terkait LK3 bersumber dari keluarga yang mengetahui keberadaan pelayanan LK3. 
Orang tua yang mengetahui kasus yang menimpa anaknya melaporkan kepada pihak berwajib/kepolisian untuk mendapatkan penanganan secara hukum. Kepolisian kemudian memberikan informasi mengenai pelayanan sosial LK3 kepada korban tindak kekerasan.

\section{b. Jenis informasi yang dimanfaatkan} Jenis informasi tersebut meliputi informasi mengenai penanganan kasus anak dan kelembagaan serta pelayanan LK3. Anak korban tindak kekerasan memperoleh informasi mengenai keberadaan LK3 untuk membantu menangani kondisi anak yang trauma, berupa bantuan pendidikan, kesehatan dan pendampingan.

\section{c. Proses pemanfaatan pelayanan informasi}

Pelayanan informasi dimanfaatkan pada awal anak korban tindak kekerasan mendapatkan pelayanan dari LK3 diawali dengan tahapan pelaporan terhadap pihak kepolisan. Anak korban kekerasan bersama dengan keluarga melaporkan kejadian kepada kepolisian untuk memperoleh penanganan kasus hukum. Informan pada awalnya tidak mengetahui keberadaan LK3 kemudian memperoleh informasi mengenai penanganan kasus yang dialaminya setelah melaporkan kepada pihak kepolisian. Hal tersebut menunjukkan bahwa adanya peran penting dari mitra kerja dalam memberikan informasi mengenai pelayanan LK3. Proses pemanfaatan pelayanan informasi dilanjutkan dengan mendatangi kantor sekeretariat LK3 yang disertai dengan pengaduan mengenai kasus yang dialami. Anak korban tindak kekerasan kemudian diberikan informasi mengenai pelayanan yang akan diberikan oleh pihak LK3.

\section{d. Intensitas penggunaan pelayanan} informasi

Intensitas dalam penggunaan pelayanan informasi mengacu kepada seberapa sering informan memanfaatkan pelayanan informasi. Berdasarkan hasil penelitian intensitas pemanfaatan pelayanan informasi cenderung jarang dilakukan. Hal ini dipengaruhi oleh kondisi anak yang masih trauma sehingga mereka kurang memanfaatkan pelayanan informasi dari pihak LK3. Selain itu, pengaruh pengetahuan dari orang tua yang terbatas mengenai bentuk dan pelayanan LK3 menyebabkan orang tua lebih berfokus pada informasi kelanjutan kasus hukum yang terjadi.

\section{e. Media yang digunakan dalam memanfaatkan pelayanan informasi}

Media yang digunakan meliputi media telepon/ tidak langsung, bertemu langsung dan melalui sosialisasi. Pemanfaatan pelayanan informasi lebih sering digunakan menggunakan media langsung. Anak korban tindak kekerasan langsung bertemu dengan pihak LK3 untuk mendapatkan informasi yang dibutuhkan. Keadaan pendidikan yang kurang dari anak maupun keluarga korban tindak kekerasan menyebabkan perlunya media seperti pamflet yang diberikan LK3 pada awal pemberian informasi atau dengan menggunakan poster untuk mempermudah sosialisasi mengenai pelayanan yang diberikan oleh LK3.

\section{Pemanfaatan Pelayanan Penjangkauan}

Direktorat Jenderal Pemberdayaan Sosial Perorangan, Keluarga dan Kelembagaan 
Masyarakat (2016) menyatakan

penjangkauan sebagai upaya-upaya memastikan bahwa mereka yang membutuhkan pelayanan sosial memperolehnya dengan cara bekerja di lapangan dan memberikan pelayanan di tempat tinggal korban. Berdasarkan hasil penelitian menunjukkan bahwa pelayanan ini diberikan dan dimanfaatkan oleh anak korban tindak kekerasan oleh pihak LK3 ketika anak tidak dapat mengakses pelayanan ke kantor sekretariat.

Pelayanan penjangkauan yang dimanfaatkan oleh anak korban tindak kekerasan dilakukan di rumahnya, hal tersebut sesuai dengan teori bahwa pelayanan penjangkauan diberikan di tempat tinggal klien.

\section{a. Tujuan pemanfaatan pelayanan penjangkauan}

Anak korban tindak kekerasan memanfaatkan pelayanan penjangkauan bertujuan untuk melaporkan perkembangan kondisi anak dan menangani kondisi anak korban tindak kekerasan yang masih trauma. Pelayanan penjangakuan juga dilakukan sebagai upaya untuk memperoleh hasil asesmen dalam menentukan rencana intervensi penanganan kasus yang dilami anak. Kegiatan penjangkauan bertujuan untuk mengontrol keadaan kesehatan, psikis, aktivitas anak korban tindak kekerasan.

\section{b. Intensitas pemanfaatan pelayanan penjangkauan}

Intensitas pemanfaatan pelayanan penjangkauan dilakukan dengan intensitas yang tidak bisa ditentukan. Hal tersebut dipengaruhi oleh kondisi dan kebutuhan anak. Intensitas tersebut sebanyak 3-4x dan pada rentang 3-6x.
Kondisi anak yang tidak secara mudah kembali pulih mempengaruhi intensitas pemberian pelayanan penjangkauan.

\section{c. Proses pemanfaatan pelayanan penjangkauan}

Proses pemanfaatan pelayanan penjangkauan dilakukan dengan adanya koordinasi mengenai waktu pelaksanaan penjangkauan antara pihak anak korban tindak kekerasan dengan LK3. Pelayanan penjangkauan tidak memiliki jadwal khusus. Hal ini disesuaikan dengan kesepakatan antara pihak pemberi dan penerima pelayanan dengan memperhatikan kesediaan dan kesibukan yang dimiliki.

Pelayanan penjangkauan dilakukan setelah adanya kesepakatan waktu, meskipun terkadang dilakukan langsung oleh pihak LK3 tanpa adanya pemberian informasi kepada pihak korban. Proses pelayanan penjangkauan disertai dengan pemberian pelayanan lain seperti konsultasi, konseling, dan pendampingan dalam mengakses pelayanan yang dibutuhkan seperti kesehatan.

\section{d. Kondisi dalam memanfaatkan pelayanan penjangkauan}

Pemanfaatan pelayanan penjangkauan ini digunakan oleh pihak keluarga ketika anak dalam kondisi trauma dan ketakutan serta kondisi anak yang menurun, atau tidak mengalami perubahan terutama terkait trauma yang dialaminya. Pihak keluarga yang merasa khawatir kemudian melaporkan kepada pihak LK3. Pemanfaatan pelayanan penjangkauan ini juga dipengaruhi oleh kondisi ekonomi keluarga yang mayoritas terhambat pada biaya transportasi jika harus pergi ke kantor sekretariat LK3. 


\section{Pemanfaatan Pelayanan Konsultasi}

Direktorat Pemberdayaan Keluarga dan Kelembagaan Sosial Kesejahteraan Keluarga (2011) pelayanan konsultasi merupakan pemberian bantuan penasihatan kepada individu maupun keluarga oleh seorang atau tim yang memiliki pengetahuan, keterampilan, kualifikasi profesional yang memadai berupa saran dan penanganan lanjutan apabila membutuhkan pelayanan lain maupun dalam mengakseskan sistem sumber.

Berdasarkan hasil di lapangan dapat diketahui bahwa pelayanan konsultasi yang dimanfaatkan oleh pihak keluarga anak korban tindak kekerasan bertujuan dalam pemecahan masalah psikososial anak sehingga hal tersebut sesuai dengan teori tersebut. Konsultasi diberikan oleh pihak LK3 dalam hal ini ialah pekerja sosial profesional. Pemanfaatan pelayanan konsultasi lebih dilakukan oleh informan untuk mengetahui perkembangan kasus hukum yang dimilikinya, informan tidak mengetahui bahwa LK3 memiliki anggota di bidang hukum dan kepolisian. Hal tersebut juga tidak disampaikan oleh LK3, sehingga pemberian informasi mengenai kasus hukum terbatas pada pihak pekerja sosial. LK3 seharusnya dapat menginformasikan dan mengakseskan terhadap tenaga profesional lainnya yang dimiliki. Hasil di lapangan juga menunjukkan bahwa peran dari tim profesi hukum kurang berjalan.

\section{a. Jenis Pelayanan Konsultasi}

Anak korban tindak kekerasan memanfaatkan pelayanan konsultasi berupa konsultasi informasi dengan jenis konsultasi penanganan kasus secara hukum, persiapan persidangan, konsultasi pola asuh/penanganan anak dan konsultasi kesehatan. Konsultasi penanganan kasus hukum terkait kelanjutan hukum kasus mengenai pelaku yang seringkali tidak segera di proses dan meminta penjelasan kepada pihak LK3. Konsultasi persiapan persidangan yang dilakukan berupa konsultasi mengenai prosedur persidangan dan apa yang diperlukan selama proses persidangan. Konsultasi penanganan anak yang dilakukan terkait bagaimana mengatasi anak yang mengalami trauma melalui keluarga. Sedangkan, konsultasi kesehatan yang dilakukan untuk mengetahui kondisi kesehatan anak korban tindak kekerasan dan kesehatan reproduksi.

b. Proses pemanfaatan pelayanan

\section{konsultasi}

Konsultasi dilakukan dengan proses timbal balik dimaksudkan sebagai proses bertanya dan pemberian informasi selama proses konsultasi antara klien dengan konsultan. Konsultasi ini dilakukan untuk memperoleh arahan dan informasi yang dibutuhkan. Proses konsultasi ini dapat dilakukan bersamaan dengan pelayanan penjangkauan maupun dengan mendatangi kantor sekretariat LK3.

c. Media pemanfaatan pelayanan konsultasi

Anak korban tindak kekerasan memanfaatkan pelayanan konsultasi dengan menggunakan media telepon genggam dan bertemu langsung. Media telepon genggam digunakan ketika terjadi keadaan darurat yang segera membutuhkan arahan dari pihak LK3. 


\section{d. Kondisi dalam memanfaatkan} pelayanan konsultasi

Pelayanan konsultasi dilakukan ketika kondisi tidak tahu atau bingung mengenai penanganan anak. Pengetahuan orang tua yang kurang dalam menangani anak yang mengalami tindak kekerasan menyebabkan mereka memanfaatkan pelayanan konsultasi. Selain itu, kondisi anak yang tidak stabil dan tidak ada perkembangan. Pada saat anak mengalami penurunan dan tidak ada perkembangan dari kondisi awal ketakutan menyebabkan orang tua cenderung berusaha memperoleh informasi dan mendapatkan penanganan dari pihak LK3

\section{Pemanfaatan Pelayanan Konseling}

Menurut Direktorat Pemberdayaan Keluarga dan Kelembagaan Sosial Kesejahteraan Keluarga (2011) menyatakan bahwa pelayanan konseling mencakup kegiatan menciptakan hubungan berdasarkan kesetaraan dan rasa saling percaya, memberikan dukungan, meningkatkan kesadaran diri, dan motivasi serta memberikan strategi dalam pemecahan masalah. Hal ini sesuai dengan kondisi di lapangan diketahui bahwa konseling yang dimanfaatkan oleh anak korban tindak kekerasan dalam rangka mengatasi permasalahan yang dialaminya berupa trauma setelah kejadian dan serta mampu menyesuaikan dengan situasi yang tidak diharapkannya. Adapun anak korban tindak kekerasan memperoleh dukungan, motivasi untuk meningkatkan kepercayaan dirinya dan keberaniannya.

Pelayanan konseling dimanfaatkan dengan tujuan dapat mengembalikan kondisi anak menjadi pulih secara sosial psikologis.
Tujuan tersebut sesuai pernyataan Thomson \& Rudolph dalam Yani Aryani (2017) bahwa konseling bertujuan untuk melakukan perubahan tingkah laku ke arah positif. Berdasarkan hasil penelitian diketahui bahwa pelayanan ini bermanfaat bagi anak korban tindak kekerasan karena melalui proses ini anak dapat kembali berinteraksi dengan lingkungan sosialnya juga dapat mengurangi rasa takut yang dimiliki sehingga terjadi perubahan perilaku anak yang takut kemudian menjadi berani.

\section{a. Jenis pelayanan konseling yang} dimanfaatkan.

Jenis konseling tersebut berupa konseling individu dan konseling keluarga. Konseling individu yang dimanfaatkan secara langsung oleh anak korban tindak kekerasan berupa pemberian semangat, dukungan emosional, dan dalam rangka meningkatkan kepercayaan diri anak dan muncul kemandirian pada diri anak. Adapun konseling keluarga berupa pemberian arahan dalam pola asuh sehingga terjadi perubaha perilaku dari anggota keluarga lainnya dalam mengatasi dan memandang anak yang mengalami kekerasan. Konseling keluarga disertai dengan pemecahan masalah dengan melihat keluarga sebagai sistem terdekat anak yang dapat membantu proses pemulihan kondisi psikososial anak.

b. Proses dalam pemanfaatan pelayanan konseling

Konseling yang dilakukan disesuaikan dengan kebutuhan dan kondisi anak. Proses konseling yang dilakukan juga menyesuaikan dengan usia anak. Proses konseling diawali dengan relaksasi terhadap anak sehingga anak yang trauma 
menjadi lebih tenang dalam mengungkapkan permasalahan yang dialaminya. Selanjutnya, anak kemudian diberikan dukungan, masukan, dan motivasi sehingga kepercayaan diri dan keberaniannya meningkat. Anak diajarkan untuk dapat berani menyatakan pendapatnya mengenai perasaan yang dialaminya dan proses kejadian yang dialaminya. Menurut Yani Aryani (2017) proses konseling dilakukan dengan beberapa tahap seperti persiapan, tahap awal, tahap eksplorasi dan sintesa. Konseling dilakukan secara langsung antara konselor dan klien dengan keadaan rileks. Berdasarkan hasil penelitian diketahui bahwa proses konseling sesuai dengan teori tersebut dimana terdiri dari beberapa tahapan yang menyesuaikan dengan kondisi anak.

Hasil dari proses konseling diharapkan anak dapat berani mengungkapkan kejadian yang dialaminya di proses persidangan, selain itu juga bertujuan agar trauma yang dimilikinya berkurang sehingga dapat berfungsi sosial kembali. Konseling ini dilakukan oleh pekerja sosial dan konselor yang dimiliki oleh LK3.

c. Media pemanfaatan pelayanan konseling

Media yang digunakan dalam pemanfaatan pelayanan konseling yaitu melalui media telepon dan bertemu langsung (face to face). Penanganan anak korban tindak kekerasan dalam proses konseling lebih dilakukan secara langsung melalui wawancara dengan anak.

\section{Pemanfaatan Pelayanan Advokasi}

Menurut Direktorat Pemberdayaan Keluarga dan Kelembagaan Sosial Kesejahteraan Keluarga (2011) pelayanan advokasi merupakan tindakan mewakili, membela kepentingan klien, pendampingan baik intervensi atau penanganan langsung dengan tujuan menjamin klien memperoleh hakhaknya. Berdasarkan hasil di lapangan diketahui bahwa proses pemanfaatan pelayanan advokasi untuk melindungi kepentingan dan hak dari anak korban tindak kekerasan.

Hasil dari pemanfaatan pelayanan advokasi ini ialah terpenuhinya hak-hak anak seperti yang tertuang menurut Konverensi Hak Anak dalam Abu Huraerah (2018) yaitu hak atas kelangsungan hidup, hak perlindungan, dan hak untuk berkembang. Advokasi yang dilakukan juga bermanfaat bahwa karena anak dapat memperoleh kesempatan untuk mendapatkan pelayanan dari pemerintah dan perlindungan khusus.

\section{a. Jenis pelayanan advokasi yang} dimanfaatkan

Pelayanan advokasi yang digunakan oleh anak korban tindak kekerasan dalam bentuk advokasi pendidikan, kesehatan, hukum baik pengadilan maupun kepolisian. Pelayanan advokasi pendidikan yang dimanfaatkan adalah sebagai upaya memenuhi kebutuhan pendidikan anak korban tindak kekerasan, dimana advokasi pendidikan diberikan ketika anak tidak dapat mengikuti proses belajar karena trauma yang dialaminya sehingga LK3 berusah meminta keringanan kepada pihak sekolah. Selain itu, advokasi pendidikan dilakukan untuk menjaga kerahasiaan kasus yang dialami oleh anak sehingga 
tidak diketahui oleh banyak pihak yang akan mengganggu proses penyembuhan anak. Advokasi pendidikan juga dilakukan berupa bantuan dalam proses perpindahan sekolah anak.

Advokasi kesehatan berupa pendampingan anak ke rumah sakit untuk memperoleh pelayanan kesehatan. Selain itu, advokasi kesehatan yang diberikan oleh LK3 terhadap anak korban tindak kekeasan agar mendapat kemudahan proses pemerikasaan kesehatan dengan diberikannya kode khusus sehingga anak tidak perlu menunggu terlalu lama dan kerahasiaan anak dapat terjaga. Advokasi hukum berupa pendampingan pada proses persidangan dan pelaporan di kepolisian.

b. Intensitas pemanfaatan pelayanan advokasi

Intensitas pemanfaatan pelayanan advokasi berdasarkan hasil penelitian dapat dikatakan sering pada informan yang memiliki permasalahan yang kompleks. Selain itu juga dipengaruhi pada proses penanganan yang lebih panjang. Adapun intensitas pemanfaatan pelayanan advokasi pendidikan sebanyak 1x. Intensitas pemanfaatan pelayanan advokasi kesehatan dan hukum sebanyak 5-7x selama proses penanganan.

\section{c. Media pemanfaatan pelayanan} advokasi

Media yang digunakan seperti telepon genggam, bertemu langsung dan melalui media cetak berupa surat. Penggunaan media surat dilakukan untuk mendapatkan advokasi berupa pendampingan persidangan.

\section{Pemanfaatan Pelayanan Rujukan}

Rujukan menurut Direktorat Jenderal Pemberdayaan Sosial Perorangan, Keluarga dan Kelembagaan Masyarakat (2016) rujukan adalah bentuk pelimpahan wewenang dan tanggung jawab atas suatu masalah atau kasus tertentu yang dilakukan secara timbal balik maupun horizontal kepada yang lebih kompeten, rasional, dan tidak dibatasi oleh wilayah administrasi. Rujukan juga diartikan sebagai tindakan pengalihan pelayanan kepada pihak lain yang dilakukan untuk memastikan klien memperoleh pelayanan sesuai dengan masalah dan kebutuhannya.

Hasil di lapangan menunjukkan bahwa anak korban tindak kekerasan telah memanfaatkan pelayanan rujukan untuk memperoleh pelayanan yang tidak tersedia di LK3 seperti pelayanan kesehatan dan perlindungan rumah aman/tempat tinggal.

\section{a. Jenis pelayanan rujukan yang} dimanfaatkan

Anak korban tindak kekerasan memanfaatkan pelayanan rujukan untuk memperoleh pelayanan yang tidak tersedia di LK3. Diketahui bahwa tidak semua informan memperoleh pelayanan rujukan. Hal ini dipengaruhi oleh kebutuhan masingmasing anak berbeda dalam penanganan masalah kekerasan yang dialaminya. Pemberian rujukan dilakukan dengan memperhatikan kesepakatan antara pihak penerima pelayanan hal ini sesuai dengan prinsip self determination. Rujukan tersebut seperti dalam memberikan perlindungan rumah aman/panti dan rujukan kesehatan.

b. Kondisi dalam memanfaatkan pelayanan rujukan

Pelayanan rujukan dimanfaatkan oleh anak korban tindak kekerasan berdasarkan hasil 
penelitian disebabkan oleh beberapa kondisi seperti anak yang terancam dan keterbatasan ekonomi. Anak korban tindak kekerasan seringkali mendapatkan ancaman dari pihak pelaku sehingga mereka membutuhkan tempat aman. Kebutuhan tempat aman belum dapat disediakan oleh pihak LK3 sehingga rujukan diberikan dengan bekerjasama dengan panti yang ada di Kota Cimahi. Anak korban tindak kekerasan yang berasal dari keluarga yang berkekurangan seringkali terhambat pada biaya sehingga tidak mampu mengakses pelayanan kesehatan. Oleh karena itu, mereka memanfaatkan pelayanan rujukan kesehatan untuk mendapatkan keringanan dengan pengajuan surat keterangan tidak mampu, dimana LK3 berkoordinasi dengan Dinas Sosial dan Dinas Kesehatan.

\section{PEMBAHASAN}

Pelayanan kesejahteraan anak sesuai yang dikemukakan oleh Suharto dalam Abu Huraerah (2018) dapat dilakukan salah satunya dengan aras model mikro dengan strategi intervensi krisis, konseling, perawatan medis, dan dukungan sosial hal ini sesuai dengan pelayanan sosial yang diberikan oleh LK3 yang terdiri dari pelayanan informasi, konsultasi, penjangkauan, konseling, advokasi, dan rujukan.. Pemanfaatan pelayanan sosial LK3 Kota Cimahi diartikan sebagai upaya atau cara yang dilakukan anak korban tindak kekerasan dalam memperoleh penanganan kondisi biopsikosialnya akibat kejadian kekerasan yang dialami.

Pelayanan sosial yang merupakan program-program yang dilaksanakan untuk menjamin suatu tingkatan dasar dan penyediaan fasilitas pemenuhan kebutuhan akan kesehatan, pendidikan, dan kesejahteraan untuk melaksanakan fungsi-fungsi untuk memperlancar kemampuan dan menjangkau pelayanan-pelayanan dan lembaga-lembaga yang telah ada dan membantu masyarakat yang mengalami kesulitan dapat terlihat dan dimanfaatkan oleh anak korban tindak kekerasan.

Pelayanan sosial anak terpadu dan berkelanjutan yang diberikan oleh LK3 selama proses monitoring dan evaluasi kurang dimanfaatkan dengan baik oleh anak korban tindak kekerasan dikarenakan beberapa informan yang kondisinya terlihat membaik dibandingkan pertama kali memperoleh pelayanan cenderung menghentikan proses penanganan. Hal tersebut sangat disayangkan karena pelayanan terhadap anak perlu memperhatikan perkembangan anak di masa selanjutnya seteah memperoleh penanganan. Kondisi tersebut dikhawatirkan akan menjadi dampak yang kurang positif dikemudian hari ketika kurangnya kesadaran untuk melakukan evaluasi terhadap perkembangan anak.

Pelayanan sosial LK3 telah berupaya memberikan pelayanan suportif menurut Kadushin (1988) yaitu meningkatkan hubungan anak dan orang tua, memperkuat kemampuan orang tua dalam memberikan pengasuhan/pemenuhan kebutuhan anak. Faktanya berdasarkan hasil penelitian di lapangan diketahui bahwa peran orang tua belum secara maksimal dalam mendukung anak untuk memperoleh pelayanan dan kurangnya hubungan baik antara anak dan orang tua mempengaruhi bentuk dukungan yang diberikan.

\section{Analisis Masalah}

Berdasarkan hasil penelitian yang telah dilakukan ditemukan bahwa pada dasarnya pemanfaatan pelayanan sosial LK3 belum secara optimal dilakukan oleh anak korban 
tindak kekerasan maupun keluarga hal ini secara umum disebabkan karena kurangnya informasi mengenai bentuk pelayanan yang diberikan oleh LK3 khususnya pada sub aspek jenis pelayanan informasi dan kurangnya sikap pro aktif dari anak maupun keluarga dalam memanfaatkannya. Permasalahan tersebut juga dipengaruhi karena kurang maksimalnya pemberian pelayanan LK3 berdasarkan hasil observasi akibat keterbatasan SDM dalam menangani kasus dibandingkan beban kerja yang dimiliki

Pemanfaatan pelayanan sosial LK3 dalam upaya peningkatan kesejahteraan anak korban kekerasan telah dilaksanakan untuk mengembalikan kondisi biopsikososial anak yang mengalami kekerasan. Hal tersebut sesuai dengan Keberadaan LK3 Kota Cimahi menjadi lembaga yang mampu mendukung upaya pemulihan anak korban kekerasan. Pelayanan sosial yang dimiliki LK3 memperlihatkan adanya peranserta yang cukup baik antara berbagai pihak dalam pemenuhan hak anak seperti perlindungan.

Pemanfaatan pelayanan sosial LK3 yang terdiri dari pelayanan informasi, penjangkauan, konseling, advokasi dan rujukan juga belum mampu dimanfaatkan secara maksimal oleh anak korban kekerasan dikarenakan kondisinya yang masih dalam keadaan trauma dan pengaruh usia. Pemanfaatan pelayanan LK3 lebih dilakukan oleh pihak keluarga. Pemberian pelayanan diberikan berdasarkan kebutuhan masing-masing anak sehingga jenis pemanfaatan pelayanan berbeda-beda. Hal ini sesuai dengan prinsip pekerjaan sosial yaitu individualisasi dimana dalam penanganan klien tidak dapat disamakan satu sama lain.

Berikut merupakan penjelasan mengenai permasalahan yang ditemukan dari beberapa aspek ialah sebagai berikut:

\section{a. Aspek Pemanfaatan Pelayanan Informasi}

Permasalahan berdasarkan aspek pemanfaatan pelayanan informasi yaitu:

1) Permasalahan pada sub aspek jenis informasi yang meliputi kurangnya informasi mengenai LK3 dikarenakan tidak disampaikan dari pihak LK3 kepada anak dan keluarga secara jelas. Selain itu, anak dan keluarga tidak mengetahui bentukbentuk pelayanan LK3 secara jelas. Permasalahan tersebut menyebabkan pihak anak maupun keluarga tidak dapat secara maksimal memanfaatkan pelayanan yang ada. Kurangnya informasi mengenai pelayanan LK3 mempengaruhi perilaku anak korban tindak kekerasan maupun keluarga dalam memanfaatkan pelayanan LK3. Mereka hanya menerima bantuan dan proses pertolongan tanpa mengetahui bagaimana yang semestinya.

2) Permasalahan pada sub aspek intensitas pemanfaatan pelayanan informasi meliputi tingkat pemahaman yang kurang dari pihak keluarga dan anak mempengaruhi proses diberikannya informasi sehingga mempengaruhi cepat dan tidaknya informasi diterima.

c. Permasalahan pada sub aspek intensitas pemanfaatan pelayanan informasi meliputi kurangnya keaktifan dari pihak keluarga dan anak dalam menggunakan pelayanan informasi. 
b. Aspek Pemanfaatan Pelayanan Penjangkauan.

Permasalahan yang diperoleh berdasarkan aspek pemanfaatan pelayanan penjangkauan yaitu:

1) Permasalahan pada sub aspek intensitas diberikannya pelayanan penjangkauan yaitu kurangnya sikap pro aktif dari pihak keluarga dalam membantu anak memperoleh pelayanan baik penjangkauan maupun pelayanan lain dari LK3. Hal ini diketahui bahwa pengaruh kesibukan orang tua dan cenderung sulit berkoordinasi terkait waktu dilakukannya penjangkauan.

2) Permasalahan pada sub aspek proses pelayanan penjangkauan yaitu kesibukan dari pihak LK3 dalam menangani beberapa kasus seringkali menyebabkan

pelayanan penjangkauan tidak bisa secara cepat diberikan.

\section{c. Aspek Pemanfaatan Pelayanan Konsultasi}

Permasalahan yang muncul berdasarkan analisis peneliti pada aspek pelayanan konsultasi ialah sebagai berikut:

1) Kurangnya pengetahuan dari pihak keluarga mengenai proses penanganan menyebabkan keluarga seringkali dipengaruhi sikap terburu-buru dalam berkonsultasi untuk segera mendapat pelayanan. Hal ini menyebabkan seringkali permasalahan hubungan yang kurang baik dengan pihak LK3.

2) Permasalahan pada aspek media dalam berkonsultasi dari pihak kelurga dipengaruhi oleh kondisi handphone yang dimilikinya tidak dalam kondisi baik sehingga menghambat dalam berkonsultasi. Kondisi tersebut seperti hp hilang dan tidak memiliki nomor LK3, kondisi ekonomi yang kurang menyebabkan keluarga tidak memiliki biaya untuk mendatangi pihak LK3, serta kondisi hp yang kurang menyebabkan sulit mendengar dengan jelas mempengaruhi informasi yang disampaikan.

\section{d. Pelayanan Konseling}

Permasalahan yang muncul berdasarkan analisis peneliti pada aspek pelayanan konsultasi ialah sebagai berikut:

Pelayanan konseling yang seringkali kurang dimanfaatkan dengan baik dikarenakan kurangnya kerjasama dan dukungan antara pihak keluarga dalam membantu anak dalam proses konseling. Kondisi anak yang belum secara psikologis pulih dan membutuhkan penanganan lebih lanjut tidak didukung oleh orang tua dalam mengakses pelayanan LK3. Bentuk sikap kurang mendukung dari orang tua seperti keluarga seperti tidak melaporkan perkembangan anak setelah diberikannya pelayanan konseling oleh LK3 yang menyebabkan ketidaktahuan LK3 terkait kebutuhan konseling lanjutan bagi anak. Kondisi tempat dilakukannya konseling kurang mendukung karena keterbatasan tempat atau fasilitas. Konseling yang diberikan oleh LK3 dilakukan di ruang konseling yang dimiliki LK3 dan di rumah anak korban tindak kekerasan, akan tetapi pada kasus kekerasan terhadap anak pada informan diketahui bahwa konseling lebih sering dilakukan di rumah korban. Hal ini dikarenakan kondisi anak yang trauma menyebabkan anak tidak mau dan sulit untuk keluar dari 
rumah. Kondisi ekonomi keluarga yang kurang terlihat dari kondisi rumah yang dimiliki seperti sempit sehingga kurang mendukung proses konseling dari segi tempat. Konseling terhadap anak korban tindak kekerasan seharusnya mampu mendukung dari segi fasilitas yang ramah anak seperti tempat yang sesuai dengan kebutuhan anak seperti adanya gambar-gambar atau penataan ruangan sesuai usia anak sehingga anak merasa nyaman dan tidak takut.

\section{e. Permasalahan pada Aspek} Pemanfaatan Pelayanan Advokasi Permasalahan yang muncul dalam proses pemanfaatan pelayanan advokasi hukum (pendampingan persidangan) yaitu kurangnya pengetahuan orang tua mengenai prosedur dan bentuk advokasi yang diberikan oleh LK3 menyebabkan keluarga merasa tidak memperoleh pelayanan sesuai yang diharapkan. Prosedur pendampingan persidangan dilakukan hanya kepada anak untuk mengurangi rasa takut, akan tetapi tidak kepada orang tua yang tidak mengetahui hal tersebut merasa pelayanan tidak sesuai harapannya karena ia sebelumnya dijanjikan akan didampingi tetapi pada kenyataannya tidak didampingi oleh LK3. Berdasarkan permasalahan tersebut dapat diketahui bahwa kebutuhan dalam mengatasi permasalahan tersebut ialah dengan perlunya meningkatkan pengetahuan terkait informasi akan pelayanan LK3, meningkatkan kesadaran pentingnya pemanfaatan pelayanan sosial LK3, peningkatan komunikasi antara anak korban tindak kekerasan dengan pihak LK3 dan peningkatan kapasitas pemberi pelayanan sehingga pemanfaatan pelayanan korban tindak kekerasan dapat berjalan secara optimal. Pemecahan masalah tersebut dapat diselesaikan dengan memanfaatkan sistem sumber baik informal, formal, maupun kemasyarakatan. Sistem sumber informal yang dapat dimanfaatkan seperti keluarga, teman sebaya, tetangga, guruguru anak korban tindak kekerasan. Sistem sumber formal yaitu sekolah. Sistem sumber kemasyarakatan seperti Dinas Sosial P2KBP3A Kota Cimahi, LK3 Kota Cimahi, P2TP2A, Polres Kota Cimahi dan RSUD Cibabat Kota Cimahi.

\section{KESIMPULAN}

Pelayanan sosial yang diberikan oleh Lembaga Konsultasi Kesejahteraan Keluarga (LK3) meliputi pelayanan dalam menangani kondisi psikososial terhadap anak yang menjadi korban tindak kekerasan sehingga dapat berfungsi sosial kembali. Pelayanan tersebut seharusnya dapat dimanfaatkan oleh anak yang menjadi korban tindak kekerasan dalam menangani permasalahan yang dimilikinya. Penelitian ini bertujuan untuk mengetahui gambaran pemanfaatan pelayanan sosial LK3 oleh anak yang menjadi korban tindak kekerasan.

Hasil penelitian terkait karakteristik informan dalam pemanfaatan pelayanan LK3 dapat diketahui bahwa usia dan tingkat pendidikan mempengaruhi pemanfaatan pelayanan LK3. Hal ini seperti yang ditemukan di lapangan bahwa usia informan yang tergolong anak belum mampu memanfaatkan pelayanan sehingga membutuhkan bantuan dari pihak keluarga. Keluarga yang memiliki tingkat pendidikan yang lebih tinggi dapat memanfaatkan pelayanan LK3 dengan cukup baik dibandingkan keluarga dengan tingkat 
pendidikan yang rendah. Pemanfaatan pelayanan seringkali dipengaruhi kebutuhan dari anak korban tindak kekerasan yang berbeda-beda.

Pemanfaatan pelayanan sosial LK3 oleh anak korban tindak kekerasan di Kota Cimahi terhadap 7 aspek fokus masalah penelitian meliputi karakteristik informan, pemanfaatan pelayanan informasi, penjangkauan, konsultasi, konseling, advokasi dan rujukan menunjukkan bahwa pemanfaatan pelayanan telah dimanfaatkan dengan baik oleh anak korban tindak kekerasan. Akan tetapi, pelayanan sosial LK3 belum dimanfaatkan secara optimal pada beberapa jenis pelayanan seperti pada aspek pelayanan informasi, penjangkauan, konsultasi, konseling, dan advokasi. Hal tersebut dikarenakan beberapa permasalahan dan hambatan baik dari jenis, proses, intensitas, dan media.

Berdasarkan hasil analisis masalah menunjukkan bahwa permasalahan pada aspek pelayanan informasi diketahui pada sub aspek jenis informasi kurangnya informasi mengenai LK3 dikarenakan tidak disampaikan dari pihak LK3 kepada anak dan keluarga secara jelas. Selain itu, anak dan keluarga tidak mengetahui bentuk-bentuk pelayanan LK3 secara jelas. Hal tersebut mempengaruhi perilaku dalam memanfaatkan pelayanan LK3. Permasalahan pada sub aspek intensitas pemanfaatan pelayanan informasi dimana pemahaman yang kurang mempengaruhi cepat tidaknya informasi diberikan. Anak korban tindak kekerasan dan keluarga cenderung kurang aktif dalam memanfaatkan pelayanan dan lebih banyak dari pihak LK3 yang memberikan pelayanan.

Permasalahan pada aspek penjangkauan yaitu hambatan kurangnya sikap pro aktif dan kerjasama dalam proses pelayanan seperti kesibukan dari orang tua dan LK3. Permasalahan pada aspek konsultasi yaitu sikap dari penerima manfaat yang terburu-buru dan cenderung dipengaruhi emosi menyebabkan konsultasi tidak dapat berjalan dengan baik. Media dari pelayanan konsultasi dengan menggunakan telefon juga menjadi permasalahan karena kondisi telepon genggam yang kurang baik menyebabkan informasi tidak tersampaikan dengan jelas. Permasalahan dalam aspek pelayanan konseling ialah dimana keluarga seringkali tidak menyampaikan perkembangan dari anak, anak yang masih belum pulih tidak didukung untuk mendapatkan pelayanan konseling lanjutan oleh pihak keluarga. Selain itu, fasilitas dari pemberian pelayanan konseling juga kurang mendukung dan perlu ditingkatkan.

Permasalahan pada aspek advokasi dimana pemahaman akan prosedur pelayanan yang kurang menyebabkan keluarga merasa tidak puas dengan pelayanan yang diberikan. Selain itu, permasalahan pemanfaatan juga dipengaruhi karena kurang maksimalnya pemberian pelayanan LK3 berdasarkan hasil observasi akibat keterbatasan SDM dalam menangani kasus dibandingkan beban kerja yang dimiliki.

Kebutuhan dalam mengatasi permasalahan tersebut ialah dengan perlunya meningkatkan pengetahuan terkait informasi akan pelayanan LK3, meningkatkan kesadaran pentingnya pemanfaatan pelayanan sosial LK3, peningkatan komunikasi antara anak korban tindak kekerasan dengan pihak LK3 dan peningkatan kapasitas pemberi pelayanan sehingga pemanfaatan pelayanan korban tindak kekerasan dapat berjalan secara optimal.

Berdasarkan permasalahan tersebut dapat diketahui bahwa perlunya meningkatkan pemanfaatan pelayanan sosial dengan 
memberikan pengetahuan dan pemahaman mengenai bentuk dan fungsi kelembagaan LK3 . Pemberian pengetahuan tersebut diharapkan meningkatkan kesadaran dalam memanfaatkan pelayanan LK3 secara maksimal. Selain itu, perlunya peningkatan kapasitas bagi pihak LK3 sehingga pelayanan yang diberikan dapat diterima dengan baik oleh anak yang mengalami tindak kekerasan dan keluarga sebagai pendamping.

\section{DAFTAR PUSTAKA}

Abu Huraerah. 2018. Kekerasan terhadap Anak. Bandung: Penerbit Nuansa.

Achmad Juntika. 2013. Dinamika Perkembangan Anak dan Remaja: Tinjauan Psikologi, pendidikan, dan Bimbingan. Bandung: PT Refika AditamaAdi Fahrudin. 2012. Pengantar Kesejahteraan Sosial. Bandung: Alfa Beta

Anni Milen. 2004. Pegangan Dasar Pengembangan Kapasitas. Yogyakarta: Pondok Pustaka

Apriawan Akbar. 2018. Delapan Provinsi Dengan Tingkat Kekerasan Pada Anak Tertinggi. Diakses pada tanggal 9 Agustus 2018 dari http://kabar3.com/ detail/6666/delapan-provinsi-dengantingkat-kekerasan-pada-anak-tertinggi

Ardia.2007. Kekerasan Perempuan dan Anak di Cimahi 20 Kasus. Diakses pada tanggal 9 Agustus 2018 dari http://bandung.bisnis.com/read/20170324/8 2444/568924/kekerasan-perempuan-dananak-di-cimahi-20-kasus

Badudu, J.S, dkk. 1996. Kamus Umum Bahasa Indonesia. Jakarta: Pustaka Sinar Harapan.

Bagong Suyanto. 2010. Masalah Sosial Anak. Jakarta, Kencana Pranada Media Group

Budhi Wibawa. 2010. Dasar-Dasar Pekerjaan Sosial. Bandung: Widya Padjajaran

Birkenmaier, Julie, Marla Berg-Weger \& Martha P. Dewees. 2014. The Practice of Generalist Social Work. New Work: Routledge

Desi Mualimah. 2016. Pelayanan Sosial Anak Jalanan dan Keluarganya di Yayasan
Pembangunan Masyarakat Kesuma Bandung. STKS Bandung.

Direktorat Jenderal Pemberdayaan Sosial dan Penanggulangan Kemiskinan.2014. Pengantar Penanganan Masalah Psikososial. Jakarta: Kementerian Sosial RI Direktorat Pemberdayaan Perorangan, Keluarga dan Kelembagaan Masyarakat. 2016. Standar Operasionl Prosedur Layanan Lembaga Konsultasi Kesejahteraan Keluarga. Jakarta: Kementerian Sosial RI

Dubois, B. dan Miley, K.K. 1992. Social Work: An Empowering Profession. Boston: Allyn and Bacon

Dwi Heru Sukoco. 2011. Profesi Pekerjaan Sosial dan Proses Pertolongannya. Bandung. STKS PRESS Bandung.

Edi Suharto. 2014. Membangun Masyarakat Memberdayakan Rakyat. Bandung: Refika Aditama 2009. Praktek Pekerjaan Sosial dengan Anak. Jakarta: Pustaka Society

Herry Koeswara.2011. Garvin tentang Group Work. Bandung: STKS Press

Https://www.viva.co.id/gayahidup/parenting/9 91216-hampir-3-000-kasus-kekerasananak-terjadi-di-tahun-2017, diakses pada 9 Agustus 2018

Hurlock, Elizabeth B,. 2003. Psikologi Perkembangan. Jakarta. Erlangga

Irawan Soehartono. 2011. Metode Penelitian Sosial Suatu Teknik Penelitian Bidang Kesejahteraan Sosial dan Ilmu Sosial Lainnya. Bandung: PT Remaja Rosdakarya. Juda Damanik. 2008. Pekerjaan Sosial Jilid 3. Jakarta: Direktorat Pembinaan Sekolah Menengah Kejuruan.

Kamtono Sunarto. 2004. Pengantar Sosiologi. Jakarta: Lembaga Penerbit Fakultas Ekonomi Universitas Indonesia.

Kodar, 2011. Pelayanan Sosial. Diakses dari http://kodarsocialwelfare.blogspot.com/201 1/12/pelayanan-sosial.html pada hari Jumat, 16 Agustus 2019 pukul 09.26 WIB

KPAI. 2017. Anak Indonesia mengalami kekerasan di rumahnya sendiri. Diakses pada tanggal 16 Desember 2018, dari https://tirto.id/737-persen-anak-indonesia- 
mengalami-kekerasan-di-rumahnya-sendiricAnG

KPIA. 2017. Kasus kekerasan anak. https://www.viva.co.id/gaya-hidup/ parenting/991216-hampir-3-000-kasuskekerasan-anak-terjadi-di-tahun-2017, diakses pada 9 Agustus 2018.

Lesmana Andy. 2014. Definisi Anak. Diakses pada tanggal 16 Desember 2018 dari https://www.kompasiana.com/alesmana/55 107a56813311573bbc6520/definisianak?page $=$ all diakses

Lina Favorita, dkk. 2009. Pedoman Penanganan Korban Tindak Kekerasan. Bandung: STKS Press

2016. Metode Pekerjaan Sosial. Bandung: STKS Press

Lexy J. Moloeng. 2005. Metodelogi Penelitian Kualitatif. Bandung: PT Remaja Rosdakarya 2011. Metodelogi Penelitian Kualitatif. Bandung: PT Remaja Rosdakarya

Nawawi Hadari. 2003. Metode Penelitian Bidang Sosial. Yogyakarta: Gajah Mada University Press

Peraturan Menteri Sosial RI No 8 Tahun 2012 tentang Pedoman Pendataan dan Pengelolaan Data Penyandang Masalah Kesejahteraan Sosial dan Potensi dan Sumber Kesejahteraan Sosial

Peraturan Menteri Sosial RI No 16 Tahun 2013 tentang Lembaga Konsultasi Kesejahteraan Keluaraga

Peraturan Menteri Sosial RI No 25 Tahun 2017 tentang Lembaga Konsultasi Kesejahteraan Keluarga

Prima Ardiansyah. 2017. Pelayanan Sosial bagi Lanjut Usia di Wisma Lansia J.

Scholastica Gerintya. 2017. 73,7 Persen Anak Indonesia Mengalami Kekerasan di Rumahnya Sendiri. Diakses pada tanggal 16 Desember 2018 dari https://tirto.id/ 737persen-anak-indonesia-mengalamikekerasan-di-rumahnya-sendiri-cAnG

Sisca Aprilia Rizki. 2013. Penyediaan Dan Pemanfaatan Layanan Konsultasi Belajar Siswa Secara Online Dalam Sistem Pembelajaran Siswa Di Kota Yogyakarta. Vol.2 No 3
Soenarti Nasution Kelurahan Geger Kalong Kecamatan Sukasari Kota Bandung. STKS Bandung.

Pusat Pelayanan Terpadu Pemberdayaan Perempuan dan Anak (P2TP2A diakses pada tanggal 16 Desember 2018 dari http://prfmnews.com/berita.php?detail=ang ka-kekerasan-terhadap-anak-di-jabar-terusnaik

Pusat Pelayanan Terpadu Pemberdayaan Perempuan dan Anak (P2TP2A)

Pusat Studi Kebijakan Publik dan Advokasi .2010. Sekilas tentang Advokasi. Diakses dari http://www.pusakacommunity.org/2010/01/sekilas-tentangteori-advokasi_6241.html pada hari Sabtu, 27 Juli 2019 pukul 15.00 WIB

Rizky Dwi Mayanti. 2015. Pemanfaatan Program Asistensi Lanjut Usia Terlantar (ASLUT) oleh Lanjut Usia Terlantar di Desa Baru Kecamatan Manggar Kabupaten Belitung Timur. STKS Bandung

Rizky Perdana. 2017. Angka Kekerasan Terhadap Anak di Jabar Terus Naik. Diakses pada tanggal 16 Desember 2018 dari http://prfmnews.com/berita.php? detail=angka-kekerasan-terhadap-anak-dijabar-terus-naik

Robert, Albert R, dkk. 2008. Buku Pintar Pekerja Sosial. Jakarta: PT BPK Gunung Mulia

Robert L. Schneider, dkk. 2014. Advokasi Pekerjaan Sosial Kerangka Baru untuk Bertindak. Bandung: STKS Press 